nhất là được tiêm Hyaluronidase thông tắc mạch càng sớm thì khả năng tái thông mạch và sự cải thiện thị lực càng cao $[1,5,6]$. Tuy nhiên thực trạng hiện nay tại Việt Nam là hết sức đáng báo động. Khi xảy ra tai biến chứng do không có chuyên môn nên các trung tâm Spa cũng không biết chuyển BN đến đâu để điều trị dẫn đến bỏ qua thời gian vàng. Chính vì vây từ đầu năm 2020 các chuyên gia đầu ngành của các BV trung ương tại Hà nội đã thống nhất đưa ra quy trình phối hợp liên chuyên khoa, liên bệnh viện, tổ chức tiếp nhận thông tin và điều chuyển BN đến trung tâm ngoại khoa có đủ các chuyên gia Phẫu thuật tạo hình Thẩm mỹ, Chẩn đoán hình ảnh can thiệp mạch, Gây mê hồi sức hiện đại, phối hợp với các chuyên gia Mắt, Tai mũi họng, Da liễu nếu cần.

\section{KẾT LUẬN}

Mất thị lực là một biến chứng hiếm gặp nhưng rất thảm khốc do tiêm chất làm đầy $\mathrm{HA}$ trong thẩm mỹ. Cho đến nay không có tiêu chuẩn vàng trong điều trị tắc ĐM mắt cũng như ĐM trung tâm võng mạc. Thành công từ $B N$ đâu tiên của Việt Nam cho thấy việc tổ chức các Đơn vị ứng cứu tai biến tiêm chất làm đầy $\mathrm{HA}$ chuyên sâu tại các Trung tâm Phẫu thuật Tạo hình Thẩm mỹ lởn, phối hợp đa chuyên khoa chẩn đoán hình ảnh, can thiệp mạch, mắt và hồi sức có thể điều trị các biến chứng nghiêm trọng này một cách tối ưu nhất.
TÀI LIỆU THAM KHẢO

1. Kapoor KM, Kapoor P, Heydenrych I, Bertossi D.Vision Loss Associated with Hyaluronic Acid Fillers: A Systematic Review of Literature. Aesthetic Plast Surg. 2020 Jun; 44(3): 929-944. Epub 2019 Dec 10.

2. Fallacara A, Manfredini S, Durini E, Vertuani S. Hyaluronic Acid Fillers in Soft Tissue Regeneration. Facial Plast Surg. 2017;33(1):87-96.

3. International Society of Aesthetic Plastic Surgeons (ISAPS) International survey on aesthetic cosmetic procedures performedin 2018. ISAPS Global Survey Press Release. 3 Dec 2019

4. Beleznay $K$, Humphrey $S$, Carruthers JD, Carruthers A. Vascular compromise from soft tissue augmentation: experience with 12 cases and recommendations for optimal outcomes. J Clin Aesthet Dermatol. 2014; 7(9):37-43.

5. DeLorenzi C. Complications of injectable fillers, part 2: vascular complications. Aesthet Surg J. 2014; 34(4):584-600.

6. Thanasarnaksorn $\mathbf{W}$, Cotofana S, Rudolph $C_{\text {, }}$ Kraisak P, Chanasumon N, Suwanchinda A. Severe vision loss caused by cosmetic filler augmentation: Case series with review of cause and therapy. J Cosmet Dermatol.J Cosmet Dermatol. 2018;17(5):712-8.

7. Chen YC, Wu HM, Chen SJ, Lee HJ, Lirng JF, Lin CJ, Chang FC, Luo CB, Guo WY. IntraArterial Thrombolytic Therapy Is Not a Therapeutic Option for Filler-Related Central Retinal Artery Occlusion. Facial Plast Surg. 2018 Jun;34(3):325-9.

8. Zhang LX, Lai LY, Zhou GW, Liang LM, Zhou YC, Bai XY, Dai Q, Yu YT, Tang WQ, Chen ML. Evaluation of Intraarterial Thrombolysis in Treatment of Cosmetic Facial Filler-Related Ophthalmic Artery Occlusion. Plast Reconstr Surg. 2020 Jan; 145(1):42e-50e.

\title{
ĐÁNH GIÁ THỰC TRANG CÔNG TÁC CHUẨN BI NGƯờI BÊNH TRƯớC MỔ CỦA ĐIỀU DƯỡNG CÁC KHOA THUỘC KHỐI NGOẠI BÊ̂NH VIÊ̂N ĐA KHOA TỈNH SƠN LA NĂM 2017
}

\section{TÓM TẮT}

Mục tiêu: Nhân xét thực trạng công tác chuẩn bị trước mổ cho người bệnh (NB) mổ theo kế hoạch của Điều dưỡng các khoa thuộc khối Ngoại, Bệnh viện đa khoa (BVĐK) tỉnh Sơn La tại thời điểm nghiên cứu; đề xuất một số giải pháp nhằm nâng cao chất lượng

*Bênh viện Đa khoa tỉnh Sơn La

**Trường Đai hoc Thành Đông

Chịu trách nhiệm chính: Phạm Thị Nhuyên

Email: nhuyenmd@yahoo.com.vn

Ngày nhận bài: 1/12/2020

Ngày phản biên khoa học: 5/1/2021

Ngày duyệt bài: 25/1/2021

\section{Tống Thị Minh Nhung*, Huỳnh Thị Bình*, Phạm Thị Nhuyên*, Đinh Ngọc Sỹ **}

chăm sóc người bệnh trước mổ tại BVĐK tỉnh Sơn La. Đối tượng và phương pháp: Nghiên cứu mô tả cắt ngang 451 NB có chỉ định mổ theo kế hoạch, tại các khoa thuộc khối Ngoai-BVĐK tỉnh Sơn La; năm 2017. Kết quả và kết luấn: Hầu hết các nối dung phải chuẩn bị cho NB trưởc mổ như: tiếp đón; hỏi bệnh; hướng dẫn làm xét nghiệm; vệ sinh các nhân trước mổ...[4,5] trong đó điêu dưỡng viên các khoa Ngoại đã chuẩn bi rất tốt $(100 \%)$, có 3 khoa thực hiênn tổt là: Ngoại tổng hợp, Chấn thương, U bướu (82.5\%). Nội dung điều dưỡng viên các khoa làm chưa tốt: Vệ sinh, sát khuẩn vùng sẽ mổ. Đề xuất giải pháp: Bệnh viện cần thường xuyên kiểm tra, giám sát, đôn đốc thực hiện các quy định về chuẩn bị người NB nhiễm khuẩn; NB trước, trong và sau phẫu thuật. 
Tư khóa: Người bệnh, trước mổ, điều dưỡng viên, khoa Ngoại.

\section{SUMMARY \\ EVALUATING THE STATUS OF PREOPERATIVE PREPARATION FOR PATIENTS ACCORDING TO THE PLAN OF NURSES OF SURGERY DEPARTMENTS AT SON LA PROVINCE GENERAL HOSPITAL 2017}

Objectives: To evaluate on the status of preoperative preparation for patients (NB) according to the plan of nurses of Surgery Departments, Son La Province General Hospital of at the time of study; proposing a number of solutions to improve the quality of preoperative patient care at Son La province General Hospital. Objects and methods: Crosssectional descriptive studies 451 patients indicated for surgery according to the plan, in departments of surgical departments- Son La province General Hospital, 2017. Results and conclusion: Most of the contents need to prepare for the patient before surgery such as: reception; ask sick; instructions for testing; hygiene of the patients before surgery...[4,5 ]in which nurses of the Surgery Department prepared very well $(100 \%)$, there are 3 departments performing well: General Surgery, Trauma, Tumor (82.5\%). The content of nurses in the departments is not doing well: cleaning and disinfecting the area where the surgery will be performed. Proposing solutions: Hospitals need to regularly inspect, supervise and urge the implementation of regulations on preparing patients for infections; NB before, during and after surgery.

Keywords: Patients, preoperative, nurses, surgical department.

\section{I. ĐĂT VẤN ĐỀ}

Phẫu thuật là một phương pháp điều trị gây sang chấn, có ảnh hưởng nhất định tới người bệnh về cả thể chất và tâm lý. Trước mỗi cuộc phẫu thuật dù lớn hay nhỏ, người bệnh và gia đình họ cần được chuẩn bị chu đáo về thể chất, tinh thần cũng như các vấn để liên quan đến cuộc mổ. Hiểu rõ các vấn đề cần phải chuẩn bị sẽ giúp cho người bệnh và gia đình hợp tác tốt với cán bộ y tế, giúp cho cuộc phẫu thuật thành công và an toàn.

Trước khi phẫu thuật, nếu chuẩn bị người bệnh không/chưa chu đáo có thể xẩy ra nhiều biến chứng, thậm chí nguy hiểm đến tính mạng và sức khỏe của họ: nếu không chuẩn bị dạ dày tốt sẽ có nguy cơ trào ngược gây suy hổ hấp trong và sau gây mê; nếu không chuẩn bị tốt về tâm lý có thể gây strees tâm lý, dễ xẩy ra biến chứng trong gây mê; sai sót về vị trí PT, hoặc mô nhầm NB nếu không xác định đúng bệnh, đúng NB trước mổ; nếu không chuẩn bi vệ sinh tốt sẽ gây nguy cơ nhiễm trùng sau phẩu thuật...[2,3]. Theo tài liệu Bộ Y tế năm 2012 NKVM 5\%-10\%.

Chuẩn bị bệnh nhân trước mổ bao gồm nhiều hoạt động của cả Bác sỹ và Điều dưỡng: thăm khám đánh giá toàn diện người bệnh $[2,3]$, điều trị các rối loạn bệnh lý trước mố, các nội dung chuẩn bị trước mổ $[3,6]$. Việc phòng ngửa biến chứng trong và sau phẩu thuât liên quan nhiều đến hoạt động chăm sóc của điều dưỡng trong các giai đoạn: chăm sóc người bệnh trước mổ, chuẩn bị và chăm sóc người bệnh trước và trong gây mê, chăm sóc người bênh sau mổ...Một số nội dung chăm sóc người bệnh trong vòng một ngày trước phẫu thuật đến khi chuyển người bệnh đi mổ của điều dưỡng như: công tác tư tưởng, cam đoan mổ, vệ sinh người bệnh, ăn uống trước mổ, làm sạch đại tràng, dùng kháng sinh dự phòng theo chỉ định, chuyển người bệnh đi mổ...nếu làm tốt sẽ góp phần tích cực làm giảm tỷ lệ biến chứng trong và sau phấu thuât, đảm bảo an toàn cho người bệnh phẫu thuật. Như vậy, vai trò của điều dưỡng trong công tác chuẩn bi bênh nhân trước mổ là hết sức quan trong.

Bênh viện đa khoa tỉnh Sơn La là một bệnh viện hạng 1, lưu lượng bệnh nhân vào mổ theo lịch thường 200 NB/ tháng (Thống kê hàng tháng của khoa Gây mê nồi sức (GMHS), Bênh viện đã thực hiện nhiều biện pháp giúp tăng cường chất lượng điều trị người bệnh, giảm biến chứng do chăm sóc và điều trị. Đối với bệnh nhân phẫu thuât, việc chuẩn bị người bệnh chu đáo trước phẩu thuâtt cũng được các khoa thường xuyên quan tâm nhằm làm giảm các nguy cơ xảy ra trong và sau phẫu thuật. Cùng với các nôi dung chuẩn bi cho người bênh trước phẫu thuật mà điều dưỡng phải thực hiên theo quy định, Phiếu chuẩn bị bệnh nhân trước phẫu thuât [1] đã được đưa vào thực hiện môt cách thường quy, nhằm mục đích kiểm tra lại lần cuối các nội dung cần chuẩn bi cho người bênh trước mổ, tránh sai sót. Tuy nhiên tại bệnh viện chưa có đánh giá nào về thực trạng công tác chuẩn bị trước mổ cho người bệnh của điêu dưỡng các khoa thuôc khối Ngoai, giúp cho Lãnh đạo và Phòng Điều dưỡng BV có cơ sở chỉ đạo, rút kinh nghiệm về công tác này.

Vì vậy, chúng tôi thực hiện nghiên cứu đề tài "Đánh giá thực trạng công tác chuẩn bị người bệnh trước mổ tại bệnh viện đa khoa tỉnh Sơn La năm 2017" nhằm mục tiêu:

1. Nhân xét thực trạng công tác chuẩn bi trước mổ cho bệnh nhân mổ theo kế hoạch của Điều dưỡng các khoa thuộc khối Ngoại bệnh viện Đa khoa tỉnh Sơn La tại thời điểm nghiên cứu.

2. Đề xuất các giải pháp nhằm nâng cao chất lượng chăm sóc phục vụ người bệnh. 
II. ĐỐI TƯỢNG VÀ PHƯƠNG PHÁP NGHIÊN CỨU

2.1. Đối tượng nghiên cứu: Tất cả người bệnh từ 18 tuổi trở lên, mổ theo kế hoạch/mổ phiên tại khoa gây mê hồi sức bệnh viện đa khoa tỉnh Sơn La.

2.2. Thiết kế nghiên cứu: Nghiên cứu (NC) mô tả cắt ngang

\subsection{Chọn mẫu và cỡ mẫu}

- Chon mẫu ngấu nhiên

- Cỡ mẫu: tất cả NB (đủ tiêu chuẩn lưa chọn) từ 18 tuổi trở lên, mổ phiên/ theo kế hoạch tại khoa Gây mê hồi sức (GMHS)tại BVĐK tỉnh Sơn La, năm 2017

2.4. Công cụ đánh giá: Thu thập thông tin bằng phương pháp phỏng vấn trực tiếpđối tượng NC (người bệnh) về các thông tin cá nhân, nội dung chuẩn bị NB trước mổ mà ĐD các khoa đã thực hiên cho NB trước khi chuyển lên phòng mổ. Thời gian phỏng vấn đối tượng NC vào thời điểm đón $\mathrm{NB}$ vào phòng mổ, trước khi tiền mê.Thông tin được điền vào phiếu điều tra.

2.5. Thời gian và địa điểm nghiên cứu

- Địa điểm: BVĐK tỉnh Sơn La.

- Thời gian: năm 2017

2.6. Xử lý số liệu: Sử dụng phần mềm thống kê SPSS 13.0

\section{KẾT QUẢ NGHIÊN CỨU}

Tổng số NB được phỏng vấn trong NC là 451

3.1. Thông tin chung về đối tượng nghiên cứu: tuổi, giới, nghề nghiệp, ...
Bảng 1. Độ tuổi của đôi tượng NC

\begin{tabular}{|c|c|c|}
\hline Tuối & Số lượng (n=451) & Tỷ lệ \\
\hline Từ 18 đến 59 & 377 & $83.6 \%$ \\
\hline$\geq \mathbf{6 0}$ & 74 & $16.4 \%$ \\
\hline Tống & 451 & $100 \%$ \\
\hline
\end{tabular}

Tỷ lệ NB trẻ dưới 60 tuối chiểm tỷ lệ cao: 83.6\%

Bảng 2. Giới tính của đôi tượng NC

\begin{tabular}{|c|c|c|}
\hline Giới tính & Số lượng (n=451) & Tỷ lệ \\
\hline Nam & 221 & $49 \%$ \\
\hline Nữ & 230 & $51 \%$ \\
\hline
\end{tabular}

Tỷ lệ NB nam và nữ tương đương nhau

Nghề nghiệp: $100 \%$ NB trong NC của chúng tôi là nhân dân; Trong khi phỏng vấn có một ŝ̂̃ NB là cán bộ viên chức, nhưng họ không sẵn sàng khi được phỏng vấn nên chúng tôi đưa vào đối tượng loại trừ.

3.2. Phân bố người bệnh theo khoa

Bảng 3. Phân bố người bệnh theo khoa

\begin{tabular}{|c|c|c|}
\hline \multirow{3}{*}{\begin{tabular}{|l|} 
Khoa \\
Khoa Ngoai tống hơp (TH)
\end{tabular}} & \multicolumn{2}{|c|}{ Số lương NB Tỷ lế } \\
\hline & $(n=451)$ & $(\%)$ \\
\hline & 123 & 27.3 \\
\hline $\begin{array}{l}\text { Khoa Ngoại chấn thương } \\
\text { (CT) }\end{array}$ & 73 & 16.2 \\
\hline Khoa Ngoaai ung bướu (UB) & 176 & 39 \\
\hline Khoa Sản & 35 & 7.8 \\
\hline $\begin{array}{l}\text { Khoa Răng Hàm Mă̆t (RHM) } \\
\text { Tai mũi Họng (TMH) } \\
\end{array}$ & 44 & 9.8 \\
\hline & & \\
\hline
\end{tabular}

Nhận xét: - Khoa Ngoại U bướu có số NB mổ cao nhất 39\%

- Khoa Sản có số NB mổ thấp nhất 7.8\%

3.3. Chuẩn bị người bệnh trước mổ của các khoa thuộc khối Ngoại

Bảng 4. Điều dưỡng Đón tiếp, thông báo, động viên NB và GD, khám bệnh, lấy dấu hiệu sinh tồn $(D H S T)$, hướng dẫn NB làm xét nghiệm $(X N)$ trước mô.

\begin{tabular}{|c|c|c|c|c|c|c|c|}
\hline Nội dung Khoa & $\begin{array}{l}\text { Mức } \\
\text { độ }\end{array}$ & THoại & $\underset{\text { CT }}{\text { Ngoại }}$ & $\underset{\text { UB }}{\text { Ngoại }}$ & $\begin{array}{l}\text { Khoa } \\
\text { sản }\end{array}$ & $\begin{array}{l}\text { Khoa } \\
\text { RHM- } \\
\text { TMH }\end{array}$ & $\begin{array}{c}\text { Tổng } \\
(n=451)\end{array}$ \\
\hline \multirow{4}{*}{$\begin{array}{l}\text { Khi vào viện chuấn bị } \\
\text { mố, điêu dưỡng tiếp } \\
\text { đón, thông báo về các } \\
\text { nội dung cần chuẩn bị } \\
\text { trước mổ với NB và GĐ }\end{array}$} & \multirow{2}{*}{$\begin{array}{c}\text { Có } \\
\text { SL (\%) }\end{array}$} & 123 & 73 & 176 & 35 & 44 & 451 \\
\hline & & $27.3 \%$ & $6.2 \%$ & $39 \%$ & $7.8 \%$ & $9.8 \%$ & $.00 \%$ \\
\hline & \multirow{2}{*}{$\begin{array}{l}\text { Không } \\
\text { SL (\%) }\end{array}$} & 0 & 0 & 0 & 0 & 0 & 0 \\
\hline & & $0 \%$ & $0 \%$ & $0 \%$ & $0 \%$ & $0 \%$ & $0 \%$ \\
\hline \multirow{4}{*}{$\begin{array}{c}\text { Điều dưỡng quan tâm, } \\
\text { động viên NB và GĐ } \\
\text { trước mổ }\end{array}$} & \multirow{2}{*}{$\begin{array}{c}\text { Có } \\
\text { SL (\%) }\end{array}$} & 123 & 73 & 176 & 35 & 44 & 451 \\
\hline & & $27.3 \%$ & $16.2 \%$ & $39 \%$ & $7.8 \%$ & $9.8 \%$ & $100 \%$ \\
\hline & \multirow{2}{*}{$\begin{array}{l}\text { Không } \\
\text { SL (\%) }\end{array}$} & 0 & 0 & 0 & 0 & 0 & 0 \\
\hline & & $0 \%$ & $0 \%$ & $0 \%$ & $0 \%$ & $0 \%$ & $0 \%$ \\
\hline \multirow{4}{*}{$\begin{array}{c}\text { Người bệnh được các } \\
\text { thây thuốc khám bệnh } \\
\text { trước mố }\end{array}$} & \multirow{2}{*}{$\begin{array}{c}\text { Có } \\
\text { SL (\%) }\end{array}$} & 123 & 73 & 176 & 35 & 44 & 451 \\
\hline & & $27.3 \%$ & $16.2 \%$ & $39 \%$ & $7.8 \%$ & $9.8 \%$ & $100 \%$ \\
\hline & \multirow{2}{*}{$\begin{array}{l}\text { Không } \\
\text { SL (\%) }\end{array}$} & 0 & 0 & 0 & 0 & 0 & 0 \\
\hline & & $0 \%$ & $0 \%$ & $0 \%$ & $0 \%$ & $0 \%$ & $0 \%$ \\
\hline \multirow{4}{*}{$\begin{array}{l}\text { Điều dưỡng hướng dẫn } \\
\text { NB làm các XN trước mổ }\end{array}$} & \multirow{2}{*}{$\begin{array}{c}\text { Có } \\
\text { SL (\%) }\end{array}$} & 123 & 73 & 176 & 35 & 44 & 451 \\
\hline & & $27.3 \%$ & $16.2 \%$ & $39 \%$ & $7.8 \%$ & $9.8 \%$ & $100 \%$ \\
\hline & \multirow{2}{*}{$\begin{array}{l}\text { Không } \\
\text { SL (\%) }\end{array}$} & 0 & 0 & 0 & 0 & 0 & 0 \\
\hline & & $0 \%$ & $0 \%$ & $0 \%$ & $0 \%$ & $0 \%$ & $0 \%$ \\
\hline
\end{tabular}


VIETNAM MEDICAL JOURNAL N¹\&2 - FEBRUARY - 2021

Điều dưỡng lấy DHST, cân nặng cho NB trước mổ

\begin{tabular}{c|c|c|c|c|c|c|} 
Có & 123 & 73 & 176 & 35 & 44 & 451 \\
\cline { 2 - 7 } SL (\%) & $27.3 \%$ & $16.2 \%$ & $39 \%$ & $7.8 \%$ & $9.8 \%$ & $\mathbf{1 0 0} \%$ \\
\hline $\begin{array}{l}\text { Không } \\
\text { SL (\%) }\end{array}$ & 0 & 0 & 0 & 0 & 0 & 0 \\
\cline { 2 - 7 } & $0 \%$ & $0 \%$ & $0 \%$ & $0 \%$ & $0 \%$ & $0 \%$ \\
\hline
\end{tabular}

Nhận xét:- Các nội dung chuẩn bị NB trước mố điều dưỡng các khoa thực hiện tốt (100\%) với các nội dung từ 1-5.

Trong NC của Đoàn Quốc Hưng và CS - Nhân xét quy trình chuẩn bị bệnh nhân trước mổ tim hở có chuẩn bị ở người trưởng thành tại khoa phấu thuật tim mạch - lồng ngực BV Hữu Nghị Việt Đức [7]; các kết quả cũng tương tự NC của chúng tôi.

Bảng 5. Điều dưỡng hướng dẫn NB vệ sinh, thay quần áo sạch, nhịn ăn, làm sạch đại tràng, dùng thuốc an thần, dùng KS dự phòng trước mố

\begin{tabular}{|c|c|c|c|c|c|c|c|}
\hline Nội dung Khoa & Mức độ & Ngoại & $\underset{\text { CT }}{\text { Ngoai }}$ & $\underset{\text { UB }}{\text { Ngoai }}$ & $\begin{array}{l}\text { Khoa } \\
\text { sản }\end{array}$ & $\begin{array}{l}\text { Khoa } \\
\text { RHM- } \\
\text { TMH }\end{array}$ & $\begin{array}{c}\text { Tổng } \\
(n=451)\end{array}$ \\
\hline \multirow{4}{*}{$\begin{array}{l}\text { ĐD thông báo, hướng } \\
\text { dẫn NB tắm gội, vS, } \\
\text { thay quần áo sạch } \\
\text { trước mồ }\end{array}$} & \multirow{2}{*}{$\begin{array}{c}\text { Có } \\
S L(\%)\end{array}$} & 123 & 73 & 176 & 35 & 44 & 451 \\
\hline & & $27.3 \%$ & $16.2 \%$ & $39 \%$ & $7.8 \%$ & $9.8 \%$ & $100 \%$ \\
\hline & \multirow{2}{*}{$\begin{array}{l}\text { Không } \\
\text { SL(\%) }\end{array}$} & 0 & 0 & 0 & 0 & 0 & 0 \\
\hline & & $0 \%$ & $0 \%$ & $0 \%$ & $0 \%$ & $0 \%$ & $0 \%$ \\
\hline \multirow{4}{*}{$\begin{array}{l}\text { ĐD dùng KS dự phòng } \\
\text { cho NB theo y lệnh }\end{array}$} & \multirow{2}{*}{$\begin{array}{c}\text { Có } \\
\text { SL(\%) }\end{array}$} & 123 & 73 & 176 & 35 & 44 & 451 \\
\hline & & $27.3 \%$ & $16.2 \%$ & $39 \%$ & $7.8 \%$ & $9.8 \%$ & $100 \%$ \\
\hline & \multirow{2}{*}{$\begin{array}{l}\text { Không } \\
\text { SL(\%) }\end{array}$} & 0 & 0 & 0 & 0 & 0 & 0 \\
\hline & & $0 \%$ & $0 \%$ & $0 \%$ & $0 \%$ & $0 \%$ & $0 \%$ \\
\hline \multirow{4}{*}{$\begin{array}{l}\text { ĐD giải thích, hướng } \\
\text { dẫn NB về ăn uống và } \\
\text { nhịn ăn trước mổ }\end{array}$} & \multirow{2}{*}{$\begin{array}{c}\text { Có } \\
\text { SL(\%) }\end{array}$} & 123 & 73 & 176 & 35 & 44 & 451 \\
\hline & & $27.3 \%$ & $16.2 \%$ & $39 \%$ & $7.8 \%$ & $9.8 \%$ & $100 \%$ \\
\hline & \multirow{2}{*}{$\begin{array}{l}\text { Không } \\
\text { SL(\%) }\end{array}$} & 0 & 0 & 0 & 0 & 0 & 0 \\
\hline & & $0 \%$ & $0 \%$ & $0 \%$ & $0 \%$ & $0 \%$ & $0 \%$ \\
\hline \multirow{4}{*}{$\begin{array}{c}\text { ĐD hướng dẫn /giúp } \\
\text { NB dùng thuốc an thần } \\
\text { trước mổ }\end{array}$} & \multirow{2}{*}{$\begin{array}{c}\text { Có } \\
\text { SL(\%) }\end{array}$} & 123 & 73 & 176 & 35 & 44 & 451 \\
\hline & & $27.3 \%$ & $16.2 \%$ & $39 \%$ & $7.8 \%$ & $9.8 \%$ & $100 \%$ \\
\hline & \multirow{2}{*}{$\begin{array}{l}\text { Không } \\
\text { SL(\%) }\end{array}$} & 0 & 0 & 0 & 0 & 0 & 0 \\
\hline & & $0 \%$ & $0 \%$ & $0 \%$ & $0 \%$ & $0 \%$ & $0 \%$ \\
\hline \multirow{4}{*}{$\begin{array}{c}\text { ĐD hướng dẫn/ làm } \\
\text { sạch đại tràng cho NB } \\
\text { trước mổ }\end{array}$} & \multirow{2}{*}{$\begin{array}{c}\text { Có } \\
\text { SL(\%) }\end{array}$} & 123 & 73 & 176 & 35 & 44 & 451 \\
\hline & & $27.3 \%$ & $16.2 \%$ & $39 \%$ & $7.8 \%$ & $9.8 \%$ & $100 \%$ \\
\hline & \multirow{2}{*}{$\begin{array}{l}\text { Không } \\
\text { SL(\%) }\end{array}$} & 0 & 0 & 0 & 0 & 0 & 0 \\
\hline & & $0 \%$ & $0 \%$ & $0 \%$ & $0 \%$ & $0 \%$ & $0 \%$ \\
\hline
\end{tabular}

Nhận xét: - 100\% NB được hướng dẫn vệ sinh, thay quần áo sạch, nhịn ăn, làm sạch đại tràng, dùng thuốc an thần, dùng KS dự phòng trước mổ;

- Tất cả các khoa đều làm tốt. Trong NC của Đoàn Quốc Hưng và CS - Nhận xét quy trình chuẩn bị bệnh nhân trước mổ tim hở có chuẩn bị ở người trưởng thành tại khoa phẫu thuật tim mạch - lồng ngực BV Hữu Nghị Việt Đức [7]; các kết quả cũng tương tự NC của chúng tôi.

Bảng 6. VS sát khuẩn vừng PT trước mô;; hướng dẩn NB cam đoan mố, tháo trang sức, VS móng tay, hướng dẫn đi tiểu trước mô; đeo băng tay có ghi rô thông tin về NB

\begin{tabular}{|c|c|c|c|c|c|c|c|}
\hline Nội dung Khoa & Mức độ & $\underset{\text { THọi }}{\text { Ngoai }}$ & $\underset{\text { CT }}{\text { Ngoại }}$ & $\underset{\text { UB }}{\text { Ngoai }}$ & $\begin{array}{l}\text { Khoa } \\
\text { sản }\end{array}$ & $\begin{array}{l}\text { Khoa } \\
\text { RHM- } \\
\text { TMH }\end{array}$ & $\begin{array}{c}\text { Tổng } \\
(n=451)\end{array}$ \\
\hline \multirow{4}{*}{$\begin{array}{c}\text { ĐD vê sinh, sát khuẩn } \\
\text { vùng mổ cho NB trước } \\
\text { mổ }\end{array}$} & \multirow{2}{*}{$\begin{array}{c}\text { Có } \\
\text { SL (\%) }\end{array}$} & 0 & 0 & 0 & 0 & 0 & 0 \\
\hline & & $0 \%$ & $0 \%$ & $0 \%$ & $0 \%$ & $0 \%$ & $0 \%$ \\
\hline & \multirow{2}{*}{$\begin{array}{l}\text { Không } \\
\text { SL(\%) } \\
\end{array}$} & 123 & 73 & 176 & 35 & 44 & 451 \\
\hline & & $27.3 \%$ & $16.2 \%$ & $39 \%$ & $7.8 \%$ & $9.8 \%$ & $100 \%$ \\
\hline \multirow{4}{*}{$\begin{array}{l}\text { Hướng dẫn NB cam } \\
\text { đoan mổ }\end{array}$} & \multirow{2}{*}{$\begin{array}{c}\text { Có } \\
\text { SL(\%) }\end{array}$} & 123 & 73 & 176 & 35 & 44 & 451 \\
\hline & & $27.3 \%$ & $16.2 \%$ & $39 \%$ & $7.8 \%$ & $9.8 \%$ & $100 \%$ \\
\hline & \multirow{2}{*}{$\begin{array}{l}\text { Không } \\
\text { SL(\%) }\end{array}$} & 0 & 0 & 0 & 0 & 0 & 0 \\
\hline & & $0 \%$ & $0 \%$ & $0 \%$ & $0 \%$ & $0 \%$ & $0 \%$ \\
\hline \multirow[b]{2}{*}{ Hướng dẫn NB tháo } & \multirow{2}{*}{$\begin{array}{c}\text { Có } \\
\text { SL(\%) }\end{array}$} & 123 & 73 & 176 & 35 & 44 & 451 \\
\hline & & $27.3 \%$ & $16.2 \%$ & $39 \%$ & $7.8 \%$ & $9.8 \%$ & $100 \%$ \\
\hline
\end{tabular}




\begin{tabular}{|c|c|c|c|c|c|c|c|}
\hline \multirow{2}{*}{$\begin{array}{c}\text { trang sức, VS móng } \\
\text { tay }\end{array}$} & \multirow{2}{*}{$\begin{array}{l}\text { Không } \\
\text { SL(\%) }\end{array}$} & 0 & 0 & 0 & 0 & 0 & 0 \\
\hline & & $0 \%$ & $0 \%$ & $0 \%$ & $0 \%$ & $0 \%$ & $0 \%$ \\
\hline \multirow{4}{*}{$\begin{array}{l}\text { ĐD đeo băng tay cho } \\
\text { NB, trong đó in rõ các } \\
\text { thông tin về NB }\end{array}$} & \multirow{2}{*}{$\begin{array}{c}\text { Có } \\
\text { SL(\%) }\end{array}$} & 123 & 73 & 176 & 0 & 0 & $372 / 451$ \\
\hline & & $27.3 \%$ & $16.2 \%$ & $39 \%$ & $0 \%$ & $0 \%$ & $82.5 \%$ \\
\hline & \multirow{2}{*}{$\begin{array}{l}\text { Không } \\
\text { SL(\%) }\end{array}$} & 0 & 0 & 0 & 35 & 44 & $79 / 451$ \\
\hline & & $0 \%$ & $0 \%$ & $0 \%$ & $7.8 \%$ & $9.8 \%$ & $17.5 \%$ \\
\hline \multirow{4}{*}{$\begin{array}{c}\text { ĐD hướng dẫn NB đi } \\
\text { tiểu trước khi lên bàn } \\
\text { mổ }\end{array}$} & \multirow{2}{*}{$\begin{array}{c}\text { Có } \\
\text { SL(\%) }\end{array}$} & 123 & 73 & 176 & 0 & 0 & $372 / 451$ \\
\hline & & $27.3 \%$ & $16.2 \%$ & $39 \%$ & $0 \%$ & $0 \%$ & $82.5 \%$ \\
\hline & \multirow{2}{*}{$\begin{array}{l}\text { Không } \\
\text { SL(\%) }\end{array}$} & 0 & 0 & 0 & 35 & 44 & $79 / 451$ \\
\hline & & $0 \%$ & $0 \%$ & $0 \%$ & $7.8 \%$ & $9.8 \%$ & $17.5 \%$ \\
\hline
\end{tabular}

Nhận xét: - Đeo băng tay có ghi thông tin về NB và hướng dần NB đi tiếu trước khi lên bàn mố: có 02 khoa (Sản và RHM/TMH) điêu dưỡng không thực hiện cho NB, chiếm tỷ lệ 17.5\%. Các khoa khác thực hiện tốt ( $82.5 \%)$ hai nội dung này.

- 100\% NB được điều dưỡng hướng dẫn cam đoan mổ, tháo trang sức, VS móng tay trước mổ.

- 100\% người bệnh không được vệ sinh, sát khuẩn vừng PT cho NB trước mổ.

Trong NC của Nguyễn Thị Huyền BV Quân Y 354 [8], nội dung này cũng chỉ thực hiện được 15.3\%

3.4. Vận chuyển NB từ khoa tới phòng mổ

Bảng 7. Vận chuyển NB từ khoa tới phòng mổ

\begin{tabular}{|c|c|c|c|c|c|c|c|}
\hline Nội dung & $\begin{array}{c}\text { Mức } \\
\text { độ }\end{array}$ & $\underset{\text { TH }}{\text { Ngoại }}$ & Ngoại & $\mathbf{N g}$ & & $\begin{array}{l}\text { Khoa } \\
\text { RHM- } \\
\text { TMH }\end{array}$ & $\begin{array}{l}\text { Tống } \\
(\mathrm{n}= \\
451)\end{array}$ \\
\hline \multirow{2}{*}{$\begin{array}{c}\text { ĐD trực tiếp đưa NB tới phòng } \\
\text { mổ }\end{array}$} & \multirow{2}{*}{$\begin{array}{l}\mathrm{SL} \\
(\%)\end{array}$} & & & & & & 451 \\
\hline & & & & & & & $100 \%$ \\
\hline \multirow{2}{*}{$\begin{array}{l}\text { ĐD không đưa NB tới phòng mố, } \\
\text { chỉ hướng dấn NB tự đi }\end{array}$} & \multirow{2}{*}{$\begin{array}{l}\mathrm{SL} \\
(\%)\end{array}$} & & 0 & & 0 & 0 & 0 \\
\hline & & $0 \%$ & $0 \%$ & $0 \%$ & $0 \%$ & $0 \%$ & $0 \%$ \\
\hline \multirow{2}{*}{$\begin{array}{l}\text { ĐD vận chuyển NB từ khoa tới } \\
\text { phòng mổ bắng xe cáng/ xe đẩy }\end{array}$} & \multirow{2}{*}{$\begin{array}{l}\mathrm{SL} \\
(\%)\end{array}$} & & & & & 0 & $11 / 451$ \\
\hline & & & & & & $0^{5}$ & $2.44 \%$ \\
\hline \multirow{2}{*}{$\begin{array}{l}\text { - NB tự đi tới phòng mố không } \\
\text { di chuyển bằng xe hoặc cáng }\end{array}$} & \multirow{2}{*}{ SL } & 1. & 11 & & 3 & 44 & $440 / 451$ \\
\hline & & $25.3 \%$ & $15.75 \%$ & $39.0 \%$ & $7.8 \%$ & $9.8 \%$ & $97.56 \%$ \\
\hline
\end{tabular}

Nhận xét: - $100 \%$ NB được ĐD các khoa trực tiếp đưa tới phòng mố.

- Chỉ có 2.44\% người bệnh (2\% ở khoa Ngoại TH, 0.44\% ở khoa Ngoại CT) được đ/dưỡng chuyển tới phòng mổ bằng xe cáng/ xe đẩy; $97.56 \%$ NB không được vận chuyển bằng xe cáng/ xe đẩy, NB tự đi tới phòng mổ.

\section{BÀN LUÂN}

4.1. Hâu hết các nội dung cân phải chuẩn bị cho NB trước mồ, đî̀u dưỡng các khoa Ngoại đã chuẩn bị tốt (100\%) gồm: tiếp đón, thông báo các nội dung cần chuấn bị trước mổ với $\mathrm{NB}$; động viên NB và gia đình (GD); hỏi bệnh; hướng dẫn làm xét nghiệm; vệ sinh các nhân trước mổ, thay quần áo sạch; giải thích mục đích, hướng dấn NB nhịn ăn trước mổ; dùng thuốc an thân; thụt tháo hoặc làm sạch đại tràng; dùng kháng sinh dự phòng; ký cam đoan mổ; điêu dưỡng trực tiểp đưa NB lên phòng mổ bàn giao cho điêu dưỡng phòng mổ; đeo băng tay có ghi thông tin về NB và hướng dẫn NB đi tiểutrước khi lên bàn mổ chỉ có 3 khoa thực hiện tốt (Ngoại tổng hợp, Chấn thương, U bướu - đạt 82.5\%).

4.2. Một số nội dung chuẩn bị trước mổ cho NB điêuu dưỡng các khoa làm chưa tốt: Vệ sinh, sát khuẩn vùng sẽ mổ - 100\% không được chuẩn bị; đeo băng tay có ghi thông tin về
NB và hướng dẫn dẫn NB đi tiểu trước khi lên bàn mổ: Không làm $17.5 \%$, gặp ở 02 khoa (Sản và Răng hàm mặt (RHM)/Tai mũi họng (TMH); vận chuyển NB từ khoa lên phòng mổ, hầu như các khoa để NB tự đi $(97.56 \%)$, không vận chuyển bằng xe đầy hoặc cáng.

4.3. Đề xuất giải pháp: Điều dưỡng ( $\mathrm{DD})$ các khoa khối ngoại bệnh viện phải thực hiện đủ các nội dung chuẩn bị trước mổ đã được quy định. Tập trung vào những nội dung chưa thực hiện hoặc thực hiện chưa tốt (vệ sinh, sát khuẩn băng vùng phẫu thuật; đeo băng tay ghi thông tin NB, hướng dẫn NB đi tiểu trước khi lên bàn mổ, chuyển NB tới phòng mổ bằng cáng hoặc xe đầy). Bệnh viện cần thường xuyên kiểm tra, giám sát, đôn đốc thực hiện các quy định về chuẩn bị người bệnh trước mổ tại các khoa Ngoại. Nhằm đảm bảo an toàn, phòng ngừa sai sót, phòng ngừa nhiễm khuân cho NB trước, trong và sau phẫu thuật. 


\section{KẾT LUẬN}

- Nghiên cứu mô tả cắt ngang 451 NB có chỉ định mổ theo kế hoạch, tại các khoa thuộc khối Ngoại - BVĐK tỉnh Sơn La; năm 2017.

- Điều dưỡng viên các khoa Ngoại đã rất tốt cho NB trước mổ như: tiếp đón; hỏi bệnh; hướng dẫn làm xét nghiệm; vệ sinh các nhân trước mổ.

- Nội dung điều dưỡng viên các khoa làm chưa tốt: Vệ sinh, sát khuẩn vùng sẽ mổ

- Đề xuất giải pháp: Bệnh viện cần thường xuyên kiểm tra, giám sát, đôn đốc thực hiện các quy định về chuẩn bị người NB nhiễm khuẩn; NB trước, trong và sau phẫu thuật.

\section{TÀI LIÊU THAM KHẢO}

1. Bênh viên đa khoa Tỉnh Sơn La, Phiếu chuẩn bị bệnh nhẩn trước mổ của điều dưỡng.

2. Trường đại học $Y$ Hà Nội - Bộ môn Gây mê hôi sức (2002), Bài giảng Gây mê hồi sức tập 1, Nhà xuất bản $Y$ hoc

3. Trường Cao đẳng Kỹ thuật $Y$ tế 1- Bộ $Y$ tế (2004), Gây mê gây tê cơ bản, Nhà xuất bản Y học

4. Bệnh việ̂n Trung Ương quân đội 108 (2015), Hướng dẫn quy định chuẩn bị người bệnh trước phẩu thuât

5. Chi hội Điêuu dưỡng Ngoại khoa Việt Nam, Chuẩn bị bệnh nhân trước mổ, Web - dieuduong ngoại.com

6. Bệnh viện 103, Bài giảng chuyên ngành GMHS chuẩn bi bệnh nhân trước mổ công tác điều dưỡng về chăm sóc người bệnh trong bệnh viện.

7. Đoàn Quốc Hưng và CS (2014), Nhận xét quy trình chuẩn bi bểnh nhân trước mổ tim hở có chuẩn bị ở người trưởng thành tại khoa PTTM-LNBV Hữu Nghi Việt Đức, Tap chí Tím Mach học Việt Nam số 63-2014

8. Bùi Thị Huyền, Đánh giá thực trang chuẩn bi và bàn giao người bệnh trước phẫu thuật tại khoa phấu thuât - GMḦS bênh viên Quân Y $3 \dot{5} 4$ năm 2015, http://www.benhvien103.vn

\section{ĐÁNH GIÁ THỰC TRANG VỀ TIÊM AN TOÀN CỦA ĐIỀU DƯỠNG VIÊN TẠI MộT SỐ KHOA CỦA BÊ̂NH VIÊ̂N 198 Bộ CÔNG AN NĂM 2014}

\section{TÓM TẮT}

Muc tiêu: Xác đinh tỷ lệ tiêm an toàn và một số yếu tổ liên quan tới tiêm an toàn của điêu dưỡng các khoa Hồi sức, Cấp cứu và khối Ngoại bệnh viện 19-8 Bộ Công An - năm 2014. Đối tượng và phương pháp: Nghiên cứu mô tả cắt nganğ; 85 điều dướng thực hiện 425 mũi tiêm cho bệnh nhân, thuộc các khoa Hổi sức, Cấp cứu và khối N̉goại bệnh viện 19-8 Bộ Công An -năm 2018. Quan sát xác định các mũi tiểm an toàn/ không an toàn dựa vào 17 Tiêu chuẩn Tiêm an toàn của Bộ Y tế. Kết qủa và kết luận: Tỷ lệ thực hiện mũi tiềm an toàn của điều dưỡng (mổi mũi tiêm đều thực hiện đúng 17 tiêu chuẩn Tiêm an toàn) là $39,76 \% ; 60,24 \%$ mũi tiêm được xác định không an toàn do không thực hiên/ hoặc thực hiên chưa đúng ít nhất 01 tiêu chuẩn Tiêm an toàn đã được Bô Y tế quy đinh. Môtt số yếu tố liên quan là: Điều dưỡng ở nhóm tuổi 41-50 có tỷ lệ thực hiện Tiêm an toàn cao nhất - 75\%; nhóm tuổi > 50 có tỷ lệ Tiêm an toàn thấp nhất: chiếm 20\%. Điều dưỡng thuộc khoa Hồi sức có tỷ lệthực hiên mũi Tiêm an toàn cào nhất: 57,5\%, khoa Ngoại Tổng hợp có tỷ lệ tiêm an toàn thấp nhất: $21,82 \%$.

\section{*Trường Đại học Kỹ thuật y tế Hải Dương \\ **Trường Đại học Thành Đông}

Chịu trách nhiệm chính: Phạm Thị Nhuyên

Email: nhuyenmd@yahoo.com.vn

Ngày nhận bài: 1/12/2020

Ngày phản biện khoa họ: $5 / 1 / 2021$

Ngày duyệt bài: 28/1/2021
Giang Thị Hằng*, Huỳnh Thị Bình*, Phạm Thị Nhuyên*, Nguyễn Duy Bảo**

Tư khóa: Điều dưỡng viên, tiêm an toàn

\section{SUMMARY}

DETERMINING THE SITUATION OF SAFE

INJECTION OF NURSES AT HOSPITAL 19-8

MINISTRY OF PUBLIC SECURITY - 2014

Objective: Determine safe injection rates and a number of factors related to safe injections of nurses in resuscitation, emergency and external hospitals 198 Ministry of Public Security - 2014. Subjects and research methods:Cross-sectional descriptive studies; 85 nurses performed 425 injections for patients, belonging to resuscitation departments, emergency department and external hospital block 198 Ministry of Public Security - 2014. Observed and identified safe / unsafe injections based on 17 Safety Injection Standards of the Ministry of Health. Results and Discussion: The rate of implementing safe injections of nurses (each injection is correctly implemented 17 standards of Safe Injections) is $39.76 \%$; $60.24 \%$ of the injections are considered unsafe due to failure to / or improper implementation of at least 1 standard of Safe Injections set by the Ministry of Health. Some related factors are: Nurses in the age group 41-50 have the highest rate of safe injection - 75\%; the age group > 50 has the lowest rate of Safe Injection: $20 \%$. Nurses in the Department of Rehabilitation have the highest rate of safe injections: $57.5 \%$, General Surgery has the lowest safe injection rate: $21.82 \%$.

Keywords: Nurses, safe injection 